\title{
SUPERVISI AKADEMIK KEPALA SMK MUHAMMADIYAH DAERAH KULON PROGO TERHADAP GURU AL-ISLAM
}

\author{
Raden Wisnu Murti \\ Program Pasca Sarjana \\ Universitas Muhammadiyah Yogyakarta \\ E-mail: rwisnumurti10@gmail.com
}

\begin{abstract}
Abstrak
Penelitian ini bertujuan untuk : (1) menganalisis seberapa dalam pengetahuan kepala SMK Muhammadiyah Daerah Kulon Progo dalam mengambil peran supervisi akademik terhadap guru Al-Islam (2) mengetahui bagaimana implementasi dan hasil pelaksanaan supervisi akademik yang dilakukan oleh kepala SMK Muhammadiyah Daerah Kulon Progo terhadap guru Al-Islam. Jenis penelitian ini adalah deskriptif dengan pendekatan Mixed Method. Subjek penelitian menggunakan siswa di SMK Muhammadiyah Kulon Progo yang serumpun. Teknik pengumpulan data menggunakan observasi, wawancara, questioner dan dokumentasi. Teknik analisis data menggunakan analisis domain yang dilakukan terhadap data yang diperoleh dari pengamatan, wawancara dengan menggunakan model sequential exploratory. Kesimpulan penelitian: (1) Kepala SMK Muhammadiyah Daerah Kulon Progo memiliki pengetahuan supervisi akademik secara baik dibuktikan dengan dibuatnya program supervisi kepala sekolah yang di dalamnya memuat unsur supervisi akademik. (2) Implementasi supervisi akademik yang dilakukan oleh kepala SMK Muhammadiyah Daerah Kulon Progo terhadap guru Al-Islam menggunakan teknik individu berupa kunjungan kelas yang diawali membuat program supervisi pembelajaran.
\end{abstract}

Kata Kunci : supervisi akademik, kepala smk muhammadiyah, guru Al-Islam

\begin{abstract}
This study aims to: (1) analyze how deeply the knowledge of the head of the Kulon Progo Regional Muhammadiyah Vocational School in taking the role of academic supervision of Al-Islam teachers (2) find out how the implementation and results of the implementation of academic supervision carried out by the head of the Muhammadiyah Vocational School of the Kulon Progo Region towards teachers Al-Islam. This type of research is descriptive with Mixed Method approach. The research subjects used students in the allied Muhammadiyah Vocational School, Kulon Progo. Data collection techniques using observation, interviews, questioners and documentation. Data analysis techniques using domain analysis conducted on data obtained from observations, interviews using a sequential exploratory model. Research conclusions: (1) The Head of the Muhammadiyah Vocational School in the Kulon Progo Region has a good knowledge of academic supervision as evidenced by the establishment of a principal's supervision program which contains elements of academic supervision. (2) The implementation of academic supervision conducted by the head of the Muhammadiyah Vocational School of the Kulon Progo Region to Al-Islam teachers uses individual techniques in the form of class visits that are initiated by making a learning supervision program.
\end{abstract}

Keywords: academic supervision, head of Muhammadiyah Senior High School, Al-Islam teacher

\section{Info Artikel}

Diterima September 2019, disetujui Oktober 2019, diterbitkan Desember 2019 


\section{PENDAHULUAN}

Supervisi mempunyai fungsi agar setiap pekerjaan yang dilaksanakan merupakan suatu hasil kerja yang sesuai dengan aturan dan norma yang telah ditetapkan. Yang menjadi fungsi sentral supervisi adalah supervisi kearah perbaikan dan peningkatan situasi pendidikan dan pengajaran pada umumnya, khususnya perbaikan dan peningkatan mutu belajar peserta didik melalui bantuan berupa bimbingan atau tuntunan kepada guru untuk melaksanakan tugas dan kewajiban dengan sebaik-baiknya.

Fokus pembeda dalam penelitian ini adalah seberapa jauh pengetahuan kepala sekolah dalam mengambil peran supervisi akademik terhap guru Al-Islam serta bagaimana implementasi supervisi akademik kepala SMK Muhammadiyah Daerah Kulon Progo terhadap kinerja guru Al-Islam dengan menggunakan pandangan serta pemahaman yang dimiliki oleh orang yang melakukan elaborasi, dan yang dijadikan indikator untuk mengukur kinerja guru Al-Islam yaitu tahap menyusun persiapan atau perencanaan, tahap melakukan proses belajar mengajar, dan tahap dalam penilaian hasil pembelajaran dibuktikan dengan lembar pelaksanaan pembelajaran dan format telaah praktik pelaksanaan pembelajaran.

Permasalahan yang berkaitan dengan supervisi akademik mata pelajaran Al-Islam yaitu pelaksanaan supervisi itu sendiri dimana seharusnya dilakukan oleh kepala sekolah tetapi hanya dilakukan oleh pengawas sekolah yang berasal dari Dinas Pendidikan dan pengawas dari Kemenag kabupaten Kulon Progo yang dilakukan melalui supervisi terpadu.

\section{METODE PENELITIAN}

Sebagai subjek dalam penelitian ini adalah kepala SMK Muhammadiyah di Kulon Progo dengan mengambil sampel empat orang kepala sekolah SMK Muhammadiyah kabupaten Kulon Progo, Daerah Istimewa Yogyakarta yaitu kepala SMK Muhammadiyah 1 Wates, kepala SMK muhammadiyah 2 Wates, kepala SMK Muhammadiyah 3 Wates, dan kepala SMK Muhammadiyah 1 Temon. Penelitian tentang supervisi akademik ini bertempat di kabupaten Kulon Progo, Daerah Istimewa Yogyakarta yang difokuskan pada sekolah-sekolah Muhammadiyah. Penelitian ini dilakukan pada tahun pelajaran 2016/ 2017 sampai dengan tahun pelajaran 2017/ 2018.

Jenis penelitian yang digunakan adalah Deskriptif dengan menggunakan pendekatan Mixed method yaitu metode penelitian yang mengkombinasikan antara metode penelitian kualitatif dengan kuantitatif sehingga diperoleh data yang lebih komprehenshif, valid, reliable dan obyektif. Pendekatan-pendekatan yang dilakukan dalam penelitian ini diawali dengan mengunakan metode yang sesuai dengan metode kualitatif menurut John W. Creswell yaitu menggunakan metode studi kasus. Prosedur utamanya menggunakan sampling purposeful (untuk memilih kasus yang dianggap penting), yang kemudian dilanjutkan dengan analisis holistic atau kasus tersebut melalui deskripsi detail atas pola-pola, koneks, dan setting dimana kasus itu terjadi.

Teknik pengumpulan data dalam penelitian yang berjudul Supervisi Akademik Kepala SMK Muhammadiyah Daerah Kulon Progo Terhadap Guru Al-Islam ini adalah menggunakan beberapa teknik observasi, wawncara, questioner, dan dokumentasi.

Analisis yang tepat dalam penelitian menggunakan analisis mixed mencakup landasan filosofis, penggunaan pendekatan kualitatif dan kuantitatif serta mengkombinasikan kedua pendekatan dalam penelitian. Metode yang tepat digunakan adalah menggunakan model sequential exploratory yaitu metode dimana proses awal menggunakan metode kualitatif dan dilanjutkan dengan metode kuantitatif. 


\section{HASIL PENELITIAN DAN PEMBAHASAN}

\section{Gambaran Umum SMK Muhammadiyah Kulon Progo}

SMK Muhammadiyah Daerah Kulon Progo yang dikepalai oleh seorang kepala sekolah dibantu oleh wakil kepala sekolah, staf dan K3, karyawan merupakan sebuah wujud dari keharmonisan dalam memajukan pendidikan. Letak SMK Muhammadiyah yang kebanyakan berada di pinggir jalan kabupaten dan provinsi menjadikan sebuah kemudahan akses untuk menuju ke sekolah.

\section{Pengetahuan Kepala SMK Muhammadiyah Daerah Kulon Progo Tentang Supervisi Akademik}

Pengetahuan supervisi yang dimiliki oleh kepala SMK Muhammadiyah Daerah Kulon Progo dikatakan baik karena mampu mendevinisikan pengertian supervisi akademik dan memiliki tiga indikator yaitu perencanaan, pelaksanaan dan hasil serta mampu mengevaluasi dan melakukan tindak lanjut supervisi akademik.

\section{Implementasi Supervisi Akademik Kepala SMK Muhammadiyah Daerah Kulon Progo}

Implementasi supervisi akademik di SMK Muhammadiyah daerah Kulon Progo sudah berjalan dengan baik karena dilakukan dengan memeriksa perangkat pembelajaran, kemudian melakukan kunjungan kelas, melakukan rapat kecil, dan dilanjutkan dengan melakukan evaluasi.

\section{KESIMPULAN DAN REKOMENDASI}

1. Kepala SMK Muhammadiyah Daerah Kulon Progo memiliki pengetahuan supervisi akademik secara baik dibuktikan dengan dibuatnya program supervisi kepala sekolah yang di dalamnya memuat unsur supervisi akademik berupa perencanaan, pelaksanaan, dan hasil supervisi serta evaluasi.

2. Implementasi supervisi akademik yang dilakukan oleh kepala SMK Muhammadiyah Daerah Kulon Progo terhadap guru Al-Islam menggunakan teknik individu berupa kunjungan kelas yang diawali membuat program supervisi pembelajaran mulai dari perencanaan, persiapan, pelaksanaan, evaluasi sampai pada proses tindak lanjut sehingga peran kepala sekolah menjadi sangat penting dimana hasil akhirnya akan digunakan sebagai bahan acuan dalam pembagian tugas terhadap guru Al-Islam pada semester berikutnya, penentuan kebijakan-kebijakan, pengusulan serta promosi jabatan terhadap guru Al-Islam. Tindak lanjut dari hasil supervisi yang dilakukan adalah dengan melakukan pendampingan secara berkala dengan memangil guru AlIslam yang dirasa kurang baik dalam mengajar untuk dibina lebih lanjut, dilakukannya workshop, dan pembuatan perangkat pembelajaran yang lebih baik. 